\title{
Prophetic : An Epistemological Offer for Legal Studies
}

\author{
Kelik Wardiono \\ Doctoral Law Program Universitas Muhammadiyah Surakarta \\ kelik.wardiono@ums.ac.id
}

DOI : https://doi.org/10.23917/jtl.v1i1.8797

\section{Submission}

Track:

Received:

10 May 2019

Final Revision:

20 June 2019

Available online:

29 June 2019

Corresponding

Author:

Kelik Wardiono

kelik.wardiono@ums.ac.id

\begin{abstract}
Purpose of the study:This article aims to define Prophetic (Islamic demystification/Islamic scholarship) which is a concept offered by Kuntowijoyo to integrate science and religion. Unlike western epistemology, prophetic includes revelation and the heart as part of the ontology. From the aspect of prophetic epistemology, it is based on synthetic and analytic approaches with transcendental structural methods, while from axiological aspects, justice with prophetic ethical values are humanization, liberation, and transcendence, becomes the goal and values.

Methodology: This research was based on a philosophical approach because it was intended to explore the epistemological building of the prophetic paradigm offered by Kuntowijoyo. The main sources of information in the form of Kuntowijoyo's writings and thoughts about the prophetic paradigm were collected through library studies. The data that have been processed were analyzed using descriptive analysis, interpretation, hermeneutics, and heuristics.
\end{abstract}

Main Findings: Prophetic can be used as one model to integrate science and religion, which is done by connecting the text with the context.

Applications of this study: This study can provide keywords that can be used as a guide to understand prophetic such as: (1) qauliyah verses, kauniyah verses, and nafsiyah verses; revelation, reason, heart, and senses, as a keyword in understanding aspects of ontology; (2) synthetic and analytic approaches with transcendental structural methods, as keywords in understanding aspects of epistemology, and; (3) justice which is based on prophetic ethical values encompassing humanization, liberation, and transcendence, as keywords in understanding the axiological aspects.

Novelty/Originality of this study: understanding the prophetic paradigm of Kuntowijoyo

Keywords: Prophetic, ontology, epistemology, axiology, prophetic. 


\section{INTRODUCTION}

One of the leading challenges faced by humans today, according to Syed Muhammad Naquib al-Attas, is modern science that is not neutral, which comes from the reflection of Western human consciousness and experience ${ }^{1}$. Epistemology imperialism, according to Ziauddin Sardar, mentions the emergence of the epistemology of western civilization as a dominant way of searching and thinking, ignoring other alternative ways of knowing, ${ }^{2}$ and has shifted the role of philosophy and religion in the development of science. $^{3}$

Correspondingly, Wan Mohd Nor Wan Daud, stated that: one of the sources of the crisis of modern human civilization today is a crisis in science and thought. Also, the core of this crisis in science and thought is rooted in the epistemological crisis; this is because the concept of science developed in the west eliminates revelation as a source of knowledge, and separates knowledge from religion. ${ }^{4}$ In Golshani's assessment, ignoring the limitations of science and denying the role of philosophy and religion in science are a naive understanding. For him, science cannot be separated from values completely; many scientific works are filled with philosophical and religious estimates. The metaphysical aspect plays a significant role in almost all levels of scientific activity. Strictly speaking, according to Golshani, it is too simple to think that philosophical and ideological commitments will never enter the structure of science. ${ }^{5}$

1 This result was opposed by Fazlur Rahman, Muhsin Mahdi, Abdus Salam, Abdul Karim Soroush and Bassam Tibi. They not only rejected but also criticized the idea of the Islamization of science. As Fazlur Rahman, for example, he argues that science cannot be converted to Islam because there is nothing bad in science. The problem is only in misusing. Science has two qualities, such as "double-edged weapons" that must be used carefully and responsibly while at the same time it is very important to use them properly when obtaining them. See more: Adnin Armas, 2007, Crisis Epistemology and Islamization of Science, Ponorogo: ISID Gontor: Center for Islamic and Occidental Studis, 2007, P.18.

2 Ziauddin Sardar, 1987, The Future of Islam, Bandung: Reader Salman, p. 86 (Ziauddin Sardar, 1987, Masa Depan Islam, Bandung: Pustaka Salman, hal. 86)

3 This is based on the understanding that human beings can only become rational and mature if all myths, religions, and abstract metaphysical philosophies are replaced by science. See more Franz Magnis Suseno, 2005, Incandescent Philosophy: From Gotholoco to Women's Philosophy, from Adam Müller to Postmodernism, Yogyakarta: Publisher Canisius, p. 12 (Franz Magnis Suseno, 2005, Pijar-Pijar Filsafat : Dari Gotholoco ke Filsafat Perempuan, dari Adam Müller ke Postmodernisme, Yogyakarta : Penerbit Kanisius, hal. 12)

4 Wan Mohd Nor Wan Daud, 2008, "Dewesternization and Islamization : Their Epistemic Framework and Final Purpose". Paper presented at a seminar on the theme of Islamization of Contemporary Sciences "organized by the Institute for Islamic Studies and Practices (LPPI) Yogyakarta Muhammadiyah University in collaboration with the Yogyakarta Thought Institute (IPI Jogja) on December 13, 2008. Compare with Adnin Armas, 2007, Dewesternisasi and the Islamization of Science, paper presented at the INSISTS sabtuan discussion on May 19, 2007.

5 Mehdi Golshani, 2003, Science and the Sacred: Sacred Science vs. Secular Science, paper of International Conference on Religion and Science in the Post-Colonial World, Yogyakarta: Universitas Gajah Mada, 2-5 Januari, p. 8. 
Therefore, it is necessary to carry out an "epistemological revolution" to answer the challenge of the hegemony of westernization of this science. ${ }^{6}$ The starting point of the revolution began to be seen as the opinion of Giancarlo Bosetti, who stated that at this time, there had been a turning point in the relationship between religion and community life. The classic version of the history of the secularization process which says that secession from religion occurs parallel to the development of secularization increasingly seems inaccurate and has been abandoned, both by postmodernist intellectuals and by militant believers. ${ }^{7}$

The opinions and understandings above, henceforth raise awareness for some scientists in the West, to think and formulate the relationship between science and religion more carefully ${ }^{8}$, accompanied by efforts to reduce the belief in scientism which has been dominating.

In such a context, there are at least three groups of opinions that have arisen among western scientists, in response to the relationship between science and religion. In the first group, figures appear as supporters of post-modernism ${ }^{9}$, which is dominated by the doctrine of nihilism, pluralism relativism.

By basing on the doctrine of nihilism, the relativism of pluralism of scientists in this group wants to deny the role of religion in science. Relativism and nihilism are doctrines about the values used by post-modernism thinkers to challenge religion. The program is the dissolution of values and the eviction of tendencies that glorify authority. It is done by reducing the meaning of values which are held in high esteem and are valued as absolute by religion and society. According to Heidegger (1889-1976), nihilism is a process, wherein the end there is nothing (truth) left. For Nietzsche the process of nihilism was the devaluation of the highest value, which led to the conclusion of the doctrine of "the death of God." Both lead to a point where humans no longer hold on to the structure of values, and

6 Syed Muhammad Naquib Al-Attas, 2010, Islam and Secularism, translated by Khalif Muammar (et al), Islam and Secularism, Bandung: Institute of Islamic Thought and Human Development (P LE) in collaboration with the Nature and Tamadun Malay Institute (ATMA), Kebangsaan Malaysia University, p. 169-176.

7 Giancarlo Bosetti, 2009, Thought to Find a Point of Contact, in Giancarlo Bosetti (ed.), Faith Against Reason: Joseph Ratzinger's Debate Against Jürgen Habermas, Yogyakarta: Canisius Publisher, Hal. 37-59. (Giancarlo Bosetti, 2009, Pemikiran untuk Mencari Titik Temu , dalam Giancarlo Bosetti (ed.), Iman Melawan Nalar: Perdebatan Joseph Ratzinger Melawan Jürgen Habermas, Yogyakarta : Penerbit Kanisius, Hal. 37-59.)

8 José Casanova, 2006, Secularization Revisited: A Reply to Talal Asad, in David Scott dan Charles Hirschkind (eds.), Powers of the Secular Modern: Talal Asad and His Interlocutors, Stanford, California: Stanford University Press, Page 12

9 Post-Modernism is seen by some as a continuation of modernism, and therefore this post-modernism still maintains understanding, liberalism, rationalism and pluralism. See Hamid FahmyZarkasyi, 2010, Ikhtiar Rebuilding a dignified Islamic Civilization, in Laode M. Kamaluddin (Ed.), On Civilization: Reigniting the Lanterns of Islamic Civilization that Had Padam, Semarang: Unissula-Press in collaboration with Publisher Republikata, p. 47-48. (Hamid FahmyZarkasyi, 2010, IkhtiarMembangunkembaliPeradaban Islam yang bermartabat, dalamLaode M. Kamaluddin (Ed.), On Civilization : MenyalakanKembaliLenteraPeradaban Islam yang SempatPadam, Semarang : Unissula-Press bekerjasamadenganPenerbitRepublikata, hal. 47-48.) 
therefore values have no meaning. A concept about anything is no longer based on something metaphysical, religious, or contains divine elements. It means that the philosophy of Nihilism aims to examine and then abolish all claims made by traditional metaphysical thought. Metaphysics, where the concept of God is the foundation of thought and value, is eliminated or eliminated. Since Nietzsche stated when metaphysics had reached a point, where the truth has been considered like God, in fact, it is nothing more than subjective values, which may be wrong as other people's beliefs and opinions. According to him, there is no difference between right and wrong; both are just false beliefs (delusory) that (both) are not reliable. Therefore if we reject mistakes, we must also reject the truth. Throwing away one means people must also throw the other (to do away with one is to do away with others too). This attack on the doctrine of nihilism against metaphysics shows clearly as an attack on religion, which is the principle of morality. ${ }^{10}$

The second group is scientists, who suggest the need for dialogue between science and religion and recognize the contribution that religion can make in science, but still place religion in an inferior position before science.

It can be seen in part from the opinions of Jürgen Habermas and Joseph Ratzinger, ${ }^{11}$ based on his personal reflection reinterpreted how the relationship between "faith" and knowledge should be, through a concept that came to be known as the postsecular society. ${ }^{12}$

Habermas responds to the current secularization process by asking questions that can be reconstructed in the form of affirmative tests:

a. To be stable, a plural society is not enough to live in vivendi mode alone, but requires a basic consensus that is not merely based on abstract principles and formal procedures;

b. In reality, the structure of a liberal society depends on the solidarity of its citizens, while this solidarity is born from spontaneous sources that are pre-political in nature;

c. The sources of solidarity can become dry due to secularization that comes out of the tracks (Entgleisung der Saekularisierung), but religious defenders also cannot be considered as having more value;

10 Hamid FahmyZarkasyi, 2010, Ikhtiar Rebuilding a Dignified Islamic Civilization, Op. Cit, pp. 47-49. (Hamid FahmyZarkasyi, 2010, IkhtiarMembangunkembaliPeradaban Islam yang bermartabat, Op. Cit, hal. 47-49.)

11 Dialogue between Jürgen Habermas and Joseph Ratzinger, seen in the subject of their discussion about Postsecularization took place at the initiative and invitation of Katholische Akademie in Munich Bvaria on January 19, 2004.

12 Giancarlo Bosetti, Op. Cit, p. 6. 
d. In the field of culture and social secularization, thereare two-ways, namely the process of mutual learning between reason and religion, by reflecting on each other's weaknesses;

e. In a post-secular society, there is a need for cognitive assumptions and normative expectations that can be shared by the group of believers, as well as by those who do not believe. ${ }^{13}$

The relation of reason with religion is seen by Habermas in terms of the interests of knowledge on the one hand and the interests of a liberal state on the other. In relation to knowledge, Habermas emphasizes that each religion or even each cultural group poses a cognitive challenge to philosophy precisely because each religion and cultural groups each has their epistemic position. The epistemic peculiarity can be a correction and criticism of philosophy itself. In relation to epistemic sources outside of philosophy, it can be said here that philosophy needs to consider the epistemic position of religion and various cultural groups in order to save cognitive content from alternative sources, thus redeeming the weaknesses of philosophy itself. However, even so, if there is a protracted conflict between faith and knowledge, according to Habermas, it is necessary to think rationally. ${ }^{14}$

With respect to it, Habermas wants to underline the urgent need today for a "double learning" process that involves secular knowledge and religious traditions. It presents three layers of epistemic challenges to the community of religious people: First, religious awareness must face cognitive dissonance born of encounters with other religions and beliefs, including those who have no religious beliefs at all. Second, the religious community must also learn to adjust to the authority of science as a monopoly holder of secular knowledge. Moreover, thirdly, the religious community must also agree on the basic premises of the constitutional state which are based on non-religious morality. ${ }^{15}$ On the other

13 Ignas Kleden, 2010, Post-Secular Society: Relationship of Intellect and Faith As well as New Needs for Adjustment, speech text of Studium Generale Theology Faculty of Sanata Dharma University, Yogyakarta August 16, 2010, Pg. 12 (Ignas Kleden,2010,Masyarakat Post-Sekular:Relasi Akal Dan Iman SertaTuntutan Penyesuaian Baru, teks pidato Studium Generale Fakultas Teologi Universitas Sanata Dharma, Yogyakarta 16 Agustus 2010, Hal. 1-2.) The term post-secular is often misunderstood. The "post" addiction should not be interpreted as a further step, as if the postsecular society is a society that has surpassed secularity (or is no longer secular), but instead is a society where the process of secularization is still ongoing (an ongoing secularization), and even deeper. What is shifting with the "post" affix there is, as Habermas asserted, a change in awareness and acceptance of the fact that religious communities and all their traditions still survive and even play an active role in secularized society.

14 Jürgen Habermas, 2009, Matters Recognized by Non-Religious Philosophers About God (again from Rawls), in Giancarlo Bosetti (ed.), Faith Against Reason: Joseph Ratzinger's Debate Against Jürgen Habermas, Yogyakarta: Canisius Publishers, pp. 37-59.(Jürgen Habermas, 2009, Hal-hal yang Diakui oleh Filsuf Non-Religius Tentang Tuhan (lagi dari Rawls), dalam Giancarlo Bosetti (ed.), Iman Melawan Nalar: Perdebatan Joseph Ratzinger Melawan Jürgen Habermas, Yogyakarta : Penerbit Kanisius, Hal. 37-59.)

15 According to Ignas Kleden the focus of Habermas's attention was on the first and second consciousness, while Ratzinger gave special attention to the second and third consciousness.See moreIgnas Kleden, 2010, Post-Secular Society: Relationship of Intellect and Faith As well as New Needs for Adjustment, speech text of Studium Generale 
hand, secular people are asked to respect the existence and role of religious people seriously, not as a "rare species that should be protected from extinction," but as equal citizens, and their rights need to be protected, respected and fulfilled like citizens. other countries. Without this sincere respect, it will also be difficult to demand political participation of religious groups in maintaining a democratic constitutional order and exacerbating Kampf culture in civil society. ${ }^{16}$

New post-secular awareness --- Habermas calls it "post-metaphysical thinking" which is "agnostic, but not reductionistic" --- seeks to restore that dialogue, which has been interrupted by the influence of scientism and its naturalistic worldview. So this dialogue addresses two directions: as a criticism of the confidence of the secularists who think that religion should be discarded, and philosophy fully merged into science; as well as the affirmation of boundaries that distinguish (not separate!) between faith and knowledge. ${ }^{17}$

On the other hand, the theological reflection from Ratzinger contains a description of the latest developments of the present world, which can be summarized in the following sections:

a. The meeting between various views of life and the flow of culture in a world that is increasingly connected to one, resulting in ethical values that are binding begin to be questioned, become unsteady, and even experience destruction;

b. A new guideline with substantial ethical evidence is needed that can motivate people, as well as political mechanisms that can encourage the implementation of these ethical guidelines;

c. In a secular world where science plays such a central role, humanity must deal with the fact that science cannot produce an ethos for itself. It can determine the direction and direction of its activities and therefore requires a philosophy that can accompany it by providing ethical grounding for science activities and ethical supervision of the implications of applying scientific results

d. Religion, which has always been dealing with questions about its credibility as a source of moral guidance, is now faced with the reason which is also questioned about its credibility (can reason guide itself?);

Theology Faculty of Sanata Dharma University, Yogyakarta August 16, 2010, p. 5 (Ignas Kleden,2010,Masyarakat Post-Sekular:Relasi Akal Dan Iman SertaTuntutan Penyesuaian Baru, teks pidato Studium Generale Fakultas Teologi Universitas Sanata Dharma, Yogyakarta 16 Agustus 2010, Hal. 5)

16 Jürgen Habermas, Loc. Cit.

17 Trisno S. Sutanto, 2010, Saving Secularization, Saving Religion: Notes on Post-Secular Communities, paper presented at the monthly discussion of the Salihara Community in Jakarta, December 2010, p. 8 (Trisno S. Sutanto, 2010, Menyelamatkan Sekularisasi, Menyelamatkan Agama: Catatan tentang Masyarakat Post-Secular, makalah yang disampaikan dalam diskusi bulanan Komunitas Salihara Jakarta, Desember 2010, Hal. 8.) 
e. Both religion and reason can be trapped in their respective pathologies, and therefore a constant dialogue between religion and reason is needed so that each can see and monitor the weaknesses that exist in him;

f. Widespread doubts about the claims about the universality of an ethical system are now exacerbated by the fallibility of positive law, due to the human error of the people who compose it;

g. Positive law must ultimately rely on natural laws that originate from nature and human nature and precede reason. ${ }^{18}$

In this case, the dialogue between reason and faith and the exchange of opinions between religion and science is always useful, because both religion and philosophy and science can fall into its pathology. Theologically translated, both religion and philosophy and science must be freed from the tendency to their respective weaknesses. Both religion and philosophy and science require redemption from their sins and possible sins. The redemption can occur if in the meeting and dialogue, each party, by reflecting on the other party, can see and realize each other's weaknesses, including weaknesses that arise because the advantages of each party are not monitored by criticism that has a clear ethical basis. ${ }^{19}$

According to Josef Kreimi, existing analyzes show that the Pope believes that there are dangerous pathologies in religion that require us to understand the divine light in mind as a means of control, with which religion can help purified. However, it is also clear, that there are pathologies of reason or conceit of the mind which because of their potential efficiency (atomic bomb, a human being as a product) pose a greater threat than pathologies in religion. Therefore reason must be aware of its limits and publicly declare its willingness to hear in dealing with the religious traditions of humanity. ${ }^{20}$

The third group is scientists, who focus their attention on the possibility of integration between science and religion (or at least spiritual aspects, mysticism or metaphysical aspects).

18 Ignas Kleden, 2010, Post-Secular Society: Relationships of Intellect and Faith As well as the Needs for New Adjustments, Loc. Cit, p. 2 (Ignas Kleden,2010,Masyarakat Post-Sekular:Relasi Akal Dan Iman SertaTuntutan Penyesuaian Baru, Loc. Cit, Hal. 2.)

19 Joseph Ratzinger, 2009, Reason and Faith: Reciprocal Exchange to Build a General Ethic, in Giancarlo Bosetti (ed.), Faith Against Reason: Joseph Ratzinger's Debate Against Jürgen Habermas, Yogyakarta: Canisius Publishers, Pg. 6077. (Joseph Ratzinger, 2009, Nalar dan Iman: Pertukaran Timbal Balik untuk Mambangun Suatu Etika Umum, dalam Giancarlo Bosetti (ed.), Iman Melawan Nalar: Perdebatan Joseph Ratzinger Melawan Jürgen Habermas, Yogyakarta : Penerbit Kanisius, Hal. 60-77.)

20 Ignas Kleden, 2010, Post-Secular Society: Relationships of Intellect and Faith As well as the Needs for New Adjustments, Loc. Cit, Hal. 7-8. (Ignas Kleden,2010,Masyarakat Post-Sekular:Relasi Akal Dan Iman SertaTuntutan Penyesuaian Baru, Loc. Cit, Hal. 7-8.) 
It can be seen in part from the efforts made by a physician Fritjof Capra, ${ }^{21}$ which tries to combine science and religion, especially modern physics with metaphysical ideas from various philosophical and religious traditions of the Far East. By basing on the consideration that on:

a. There is an error in Cartesian and Newtonian physics that sees all matter only as inanimate matter;

b. The roots of the development of science stem from Greek philosophy, especially from the Milesian school of thought, which can be said to be very similar to the monistic and organic concept of thought of ancient Indian and Chinese philosophy;

c. The necessity of changing the paradigm of knowledge, from conceptual knowledge to experimental knowledge, so that we can directly meet reality itself. By placing intuitive knowledge above rational knowledge, this experimental knowledge goes beyond intellectual knowledge and sense perception;

d. The need to incorporate the concept of Pantheism from Eastern Mysticism as a scientific paradigm, which is to see the whole existence as a single existence, which is unified and unnecessary and indistinguishable. With the acceptance of Pantheism and Mysticism entering the world of science, all material realities are now seen as a living reality. The movement of electrons in wood molecules is interpreted as a material of life. More sharply, it can be said that things that have been considered dead, are now considered living, even on a par with humans;

e. All reality is basically single, so there is no single phenomenon that can be contradicted. $^{22}$

Because this paradigm offered by Capra (1) supports Einstein's hypothesis of relativism; (2) uplifting the spirit of humanism at its peak, namely placing humans with their intuitions at the center of all scientific ideas and interpretations of nature, and rejecting the view of the creation of this world by a sovereign God; (3) supports the relativity of the scientific paradigm, as suggested by Thomas Khun through his scientific paradigm; (4)

21 Besides Fritjof Capra, other scientists who try to integrate science (physics) with mysticism are Bateston, Michel Talbot, who saw that Hindu mystics since thousands of years ago have been able to "see" what is currently found in contemporary physics laboratories; and Brian Haines, who stated the need for mysticism to provide illumination of natural phenomena that are often paradoxical, because new physics can hear echo from reality (God).See more, Mulyadhi Kartanegara, 2007, Islamizing Reason: A Response to Modernity, Jakarta: Erlangga Publisher, Hal. 108109. (Mulyadhi Kartanegara, 2007, Mengislamkan Nalar: Sebuah Respon terhadap Modernitas, Jakarta : Penerbit Erlangga, Hal. 108-109.)

22 Fritjof Capra, 2009, The Tao of Physic: An Exploration of The Parallels bertween Modern Physics and Easter Mysticism, translated by Aufiyah Ilhamal Hafidz, The Tao of Physic: Menyingkap Kesejajaran Fisika Modern dan Mistisme Timur, 4th Edition, Yogyakarta: Jalasutra Publisher, p. 60-77. 
supports the assumption that since humans left God and headed for atheism, they basically experienced spiritual drought. It raises awareness of the importance of metaphysical aspects of human life. However, humans are not willing to return to God, so eventually they are more inclined to adopt Eastern Mysticism, which gives metaphysical satisfaction, without the need to acknowledge a sovereign God and sinful humans, ${ }^{23}$ then the paradigm of Capra which came to be known as the New Age Movement, ${ }^{24}$ received relatively good acceptance in the western world.

Based on the above description, we can see the importance of efforts to reconstruct epistemology, ${ }^{25}$ which on the one hand seeks to free humans from the shackles of magical, mythological, animistic and cultural traditions that conflict with religion. While on the other hand at the same time trying to free humans from the influence of secular thought on their minds and languages, or human liberation from their physical impulses which tend to be secular and unjust to their true nature or human nature. ${ }^{26}$

To do that all changes need to be made, not only in the practical operational level but --- and more importantly --- at the paradigm level or world view, ${ }^{27}$ as part of efforts to build a civilization. One alternative that can be chosen to carry out the epistemological reconstruction is to base it on the prophetic paradigm offered by Kuntowijoyo, who tries to integrate science and religion.

23 Sutjipto Subeno, 2011, Fritjof Capra's Science-Mystical Paradigm: A Critical Review From the Christian Faith Viewing Point, http://www.grii-andhika.org/makalah_penting.htm. (Sutjipto Subeno, 2011, Paradigma Sains-Mistis Fritjof Capra: Suatu Tinjauan Kritis Dari Sudut Pandang Iman Kristen, http://www.griiandhika.org/makalah penting.htm.)

24 New Age, interpreted as an era that seeks to convince many people that the most appropriate way to solve various personal and social problems - which have become part of the crisis of western culture that drives the emergence of New Age--will only be resolved, if there are enough people achieving what is called The Higher Consciousness. See more John Naisbitt, 1997, The Eight Megatrends that are Changing the World, translated by Danan Priyatmoko dan Wandi S. Brata, Megatrends Asia: Delapan megatrend Asia yang Mengubah Dunia, Jakarta: Periplus Editions and PT. Gramedia Pustaka Utama, p. 125-126. Compare with Budhy Munawar Rachman, 2001, Islam Pluralis: Wacana Kesetaraan Kaum Beriman, Jakarta: Paramadina, Hal. 99. (Budhy Munawar Rachman, 2001, Islam Pluralis: Wacana Kesetaraan Kaum Beriman, Jakarta: Paramadina, Hal. 99.) Sutjipto Subeno, 2011, Paradigma Sains-Mistis Fritjof Capra: Suatu Tinjauan Kritis Dari Sudut Pandang Iman Kristen, http://www.grii-andhika.org/makalah_penting.htm. (Sutjipto Subeno, 2011, Paradigma Sains-Mistis Fritjof Capra: Suatu Tinjauan Kritis Dari Sudut Pandang Iman Kristen, http://www.grii-andhika.org/makalah_penting.htm.)

25 Adi Setia, 2007, Three Meanings of Islamic Science: Towards Operationalization of the Islamization of Science, Journal of Islamic Thought and Civilization, Vol. III. No. 4, 2007, Jakarta: INSISTS and Publisher Khairul Bayan, p. 48. (Adi Setia, 2007,Tiga Makna Sains Islam : Menuju Pengoperasionalan Islamisasi Sains, Jurnal Pemikiran dan peradaban Islam, Vol. III. No. 4, 2007, Jakarta: INSISTS dan Penerbit Khairul Bayan, hal. 48.)

26 Hamid Fahmy Zarkasyi, Op. Cit. Hal. 65.

27 Konsep Paradigma menurut Thomas S. Khun tersebut menurut Hamid Fahmy Zarkasyi, sama artinya dengan world view. Lihat lebih lanjut Hamid Fahmy Zarkasyi, Ibid. Hal. 21. 


\section{RESEARCH METHODOLOGY}

This research was based on a philosophical approach because it was intended to explore the epistemological building of the prophetic paradigm offered by Kuntowijoyo. The main sources of information in the form of Kuntowijoyo's writings and thoughts about the prophetic paradigm were collected through library studies. The data that have been processed were analyzed using descriptive analysis, interpretation, hermeneutics, and heuristics.

\section{RESULTS AND DISCUSSION}

According to Kuntowijoyo, there are 2 patterns: integrating science and religion. First is the Islamization of science. This idea from the outset distinguished explicitly between secular social science and Islamic social science. The Islamization of knowledge strives so that Muslims do not merely imitate methods from outside (the west), and return knowledge to its center, namely monotheism. This monotheism will lead to 3 types of unity, namely: the unity of knowledge (knowledge must lead to one truth), the unity of life (erasing the difference between value-laden science and value-free science) and historical unity (knowledge must serve the people and humans.According to scientists who offer this model, as long as Muslims do not have their methodology, Muslims will always be in danger, because the anthropocentric secular science methodology eliminates religion as one source of knowledge, Islamization of knowledge seeks to return knowledge to monotheism so that there is coherence between context and text and science is inseparable from the faith. $^{28}$

Second, Islamic Science (prophetic/demystified). The demystification movement is intended as an intellectual movement to reconnect texts with context, resulting in correspondence Kedua, Pengilmuan Islam (prophetic/demystification). ${ }^{29}$ It is mainly due to the process of mystification of reality, so religion has lost contact with reality, with reality, with actuality, with life. In other words the text loses context.

When examined more deeply, the rejection of most scientists of the idea to include religion as an integral part of tacit science is actually normative as well. They believe that the only valid truth in science is empirical truth or rational truth, the truth that comes from sensible facts or truths that can be understood by human ratios. This attitude is tantamount to an exclusive normative attitude, rejecting the possibility of other truths.

\footnotetext{
Kuntowijoyo, Islam Sebagai Ilmu... Ibid, Hal. 8. Ibid.
} 
Therefore it is crucial to ease tensions between the two parties' an integral part of social science - given the importance of this to the future of humanity - must also take into account the possibility of carrying a normative approach that has so far been proven to be unable to do anything what, when dealing with reality.

There is a weakness in positivism that empowers empirical truth and its quantitative nature, as well as criticism of interpretive social science - although at some level it will agree on its interpretative nature - in its spirit that is free of values, understands reality and leaves it as it is, impartial. Encourage some people to display social science that has alignments with humanitarian goals as critical theory, so that social science does not only serve the interests of the social status quo behind its value-free claims but something more than that.

It is just that even so critical social science does not mean it does not contain criticism. Criticism of social science is mainly focused on the situation, where he never talked about religious values as an essential part of scientific work building theory. It is as if religion cannot contribute anything in constructing theoretical buildings of emancipatory social science.

Based on the background of the problem, Kuntowijoyo put forth his big idea that seemed quite promising, namely prophetic social science. This idea has similarities with critical theory, only that Kuntowijoyo has more offers because he also carries transcendence as an important part of the pillars of social science in addition to humanization and liberation.

Herein lies the difference between Islamic scholarship and the Islamization of science. Islamic scholarship is not a form of reaction to scientific buildings that have manifested and are in conflict with Islamic values. The methodology used in the "Islamic science" movement not only deals with scientific issues but also attempts to contextualize religious texts (trying to link religion to reality). Another term that can be used here is "grounding Islam," and the reality of life is the context of diversity. ${ }^{30}$

Prophetic social science, for Kuntowijoyo, is basically also transformative social science, that is, knowledge based on the results of "the elaboration of religious teachings into the form of social theory." The main goal is "engineering for social transformation. Therefore the scope is not on normative aspects that are permanent as in theology, but on

30 Zainal Abidin Bagir, Pengilmuan Islam dan Integrasi Ilmu dengan Etika: Gagasan Kuntowijoyo, disampaikan dalam seminar Apresiasi Hidup dan Pemikiran Kuntowijoyo, di University Center UGM, 26 Mei 2005, Hal. 7-8. (Zainal Abidin Bagir, Pengilmuan Islam dan Integrasi Ilmu dengan Etika: Gagasan Kuntowijoyo, disampaikan dalam seminar Apresiasi Hidup dan Pemikiran Kuntowijoyo, di University Center UGM, 26 Mei 2005, Hal. 7-8.) 
aspects that are empirical, historical, and temporal. Transformative social science "does not stop just to explain social phenomena but also seeks to transform them". The problem then is, "in what direction was the transformation carried out, for what and by whom? To these questions, transformative social science does not provide an explanation. Therefore, Kuntowijoyo then proposed the existence of prophetic social sciences, namely social sciences "which not only explained and changed social phenomena, but also gave directions in which direction the transformation was carried out, for what and by whom. Prophetic social science does not merely change for the sake of change, but changes based on prophetic ethical ideals. ${ }^{31}$ For this reason, according to Kuntowijoyo, epistemological reconstruction is needed.

Kuntowijoyo's offer of integration between science and religion is based on a crisis, ${ }^{32}$ that does not just happen in knowledge, ${ }^{33}$ but also crisis in society. ${ }^{34}$ Prophetic social sciences try to combine the critical abilities of social science and religious values in one integrated and integral paradigm of social science. Based on the transcendental structuralism method derived from Ali Imran's letter (3) verse 110, Kuntowijoyo included the element of transcendence in the building of critical theory. The values in Surah AliImran (3) verse 110 are then the pillars to develop the prophetic concept and become the paradigmatic features, namely: humanistic/theocentric humanism (ta'muruna bil-ma'ruf), liberation (tanhauna anil munkar) and transcendence (tu'minuna billah). ${ }^{35}$

Prophetic relies on Islamic scholarship (the effort to "demystify Islam"), which is moving from text to context, which is supported by objectification processes or objectivism

31 Heddy Shri Ahimsa Putra, 2011. Prophetic paradigm: Is it possible? Is it necessary ?. ((Heddy Shri Ahimsa Putra, 2011. Paradigma Profetik: Mungkinkah? Perlukah?.) Paper presented in "2011 Prophetic Workshop". organized by the UGM Postgraduate School. in Yogyakarta. February 10, 2011., p. 7.

32 A science (activity) is said to have a crisis, not only if the science (activity) is no longer able to fulfill its objectives, but also no longer able to formulate what will be fulfilled with the activity to be done. In this case the autonomy of science and research activities no longer exist, because of the enormous dependence on something that is outside him (being in a helpless state). A situation is said to be a crisis, when a person finds that subjectively he is no longer able to overcome the objective situation at hand, and is temporarily out of his ability to control his own power. Thus the crisis arises based on the inner view of the person experiencing the crisis. See more Daniel Dhakidae, 2003, Scholar and power in the New Order State. Jakarta: PT. Gramedia Main Library, pp. 333-334. (Daniel Dhakidae, 2003, Cendikiawan dan kekuasan Dalam Negara Orde Baru. Jakarta: PT. Gramedia Pustaka Utama, hal 333-334.)

33 This crisis is more concerned with the narrowing of knowledge as a result of methodological reductions offered and practiced by the schools of positivism, which are accompanied by fragmentation and instrumentalization of knowledge. See more (F. Budiman Hardiman, 2003, Beyond Positivism and Modernity: Philosophical Discourse on Scientific Methods and Problems of Modernity, Yogyarakta: Canisius Publishers, pp. 50-51.) (F. Budiman Hardiman, 2003, Melampaui Positivisme dan Modernitas: Diskursus Filosois tentang Metode Ilmiah dan Problem Modernitas, Yogyarakta :PenerbitKanisius,, hal. 50-51.)

34 Humanitarian crises occur, because positivism which seeks to educate (rationalize) people and their lives, in turn, instead impoverishes and empties the meaning of human life, until it finally instrumentalises humans. The totality of scientism divides people up to the roots of its integration. See more F. Budiman Hardiman, Ibid, p. 54.

35 Ibid. pp. 364-365 
methodologies. ${ }^{36}$ Objectification is a process to make Islamic values in the Qur'an acceptable to humankind regardless of their origin. The prophetic paradigm offered by Kuntowijoyo has the following characteristics: First, prophetic has three important values as its foundation, namely humanization, liberation, and transcendence. These three values, in addition to functioning criticism will also give direction, field or field of research; Second, epistemologically, prophetic sociology holds that there are three sources of knowledge, namely empirical reality, ratios, and revelation. It is contrary to positivism, which sees revelation as part of a myth. Third, prophetically methodologically clearly standing in a position vis-a-vis positivism. Prophetic reject positivist claims such as valuefree claims and claims that what is legitimate as a source of knowledge are sensed facts. Prophetic also reject the tendency of social science only to explain or understand reality and then forgive it. Prophetic not only understand but also have transformative ideals (liberation, humanization, and transcendence). In this sense prophetic sociology is closer to the methodology of critical sociology (critical theory). Through liberation and humanization prophetic sociology is aligned with the emancipatory interests of critical sociology. The difference is prophetic also carries transcendence as one of its goal values and becomes the basis of liberation and humanization. Fourth, Prophetic has an ethical alignment that consciousness (superstructure) determines the material base (structure).

The prophetic paradigm offered by Kuntowijoyo has a big agenda: epistemological reconstruction. Namely: first, it must be able to dismantle the roots of the revelation from the realm of science and then prove that the real revelation can legitimately become part of the epistemology of social science. Second, through the Qur'anic paradigm, epistemological reconstruction must also be able to provide methodological foundations to be able to bring revelation into the social science arena. For this purpose, the theological-normative approach that has been so hegemonic must be changed to an empirical-factual approach.

36 This objective word is not objectivity meant by positivism. Positivism states that to achieve the objectivity of a social scientist must free himself from the perceptions, pre-conceptions, pre-conceptions or values in his scientific activities. See M. Fahmi, 2005, Islam Transendental (Menelusuri jejak-jejak Pemikiran Islam Kuntowijoyo), Yogyakarta: Pilar Media, p. 270. (M. Fahmi, 2005, Islam Transendental (Menelusuri jejak-jejak Pemikiran Islam Kuntowijoyo), Yogyakarta: Pilar Media, Hal. 270.) What he refers to as objectification is nothing but the translation of religious subjective values in objective categories that can be understood by everyone without the need to understand the original values (religion) and can be agreed by anyone without having to agree on the origin values. Objectification is a method for presenting religion more scientifically, not ideologically normative. In objectification, the objective values of all religions, ideologies, beliefs or philosophical streams can communicate with each other, apart from their ideological egocentrism and then transformed into consciousness based on science rather than ideology or myth. To be able to do this, the religious teachings or values must first be changed to be objective. To be able to do this, it is necessary to shift the paradigm of Islamic teaching that emphasizes individual piety, becomes an objective which emphasizes social piety and leads to morality. Objectification is a process to make Islamic values in the Qur'an acceptable to mankind regardless of their origin. See more Kuntowijoyo, Muslim Without Mosque, Op. Cit, Hal. 373; Kuntowijoyo, Political Identity of Muslims, Bandung: Mizan, 1997, Pg. 158 (Kuntowijoyo, Muslim Tanpa Masjid, Op. Cit, Hal. 373; Kuntowijoyo, Identitas Politik Umat Islam, Bandung: Mizan, 1997, Hal. 158). 
The orientation of the text must be changed towards the orientation of reality. Kuntowijoyo's ideas about the methodology of objectivism or objectification can be understood in this context.

The Prophetic Paradigm model offered by Kuntowijoyo, can be seen in the picture below

ONTOLOGI

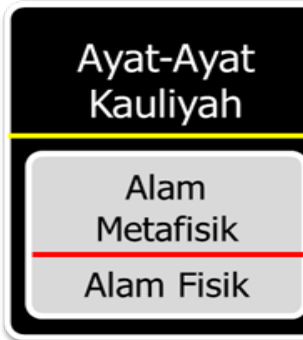

Ayat-ayat Kauniyah

Ayat-ayat Nafsiyah

\section{EPISTEMOLOGI}

Transformasi Psikologis

nilai

SINTETIK

Konstruk teoretis

METODE STRUKTURAL

TRANSENDENTAL

Transformasi Sosial

KEADILAN YANG BERTUMPU PADA KESADARAN SEJARAH DAN BERDASAR CITA ETIS PROFETIK

\section{AKSIOLOGI}

TRANSLATION:

\begin{tabular}{|l|l|l|}
\hline Ontology & Epistemology & \\
\hline kauliyahverses & psychological transformation & \\
metaphysical nature & value & Synthetic \\
physical nature & theoretical construct \\
kauniyah verses & transcendental structural \\
verses nafsiyah & \\
justice which is based on & $\begin{array}{l}\text { methods } \\
\text { historical awareness and based } \\
\text { on prophetic ethical ideals }\end{array}$ & Analytic \\
\hline
\end{tabular}

Keywords that can be used as a guide to understanding the prophetic paradigm of Kuntowijoyo, are (1) verses of qauliyah, verses of kauniyah and verses of nafsiyah; revelation, reason, heart, and sensesas a keyword in understanding aspects of ontology; (2) synthetic and analytic approaches with transcendental structural methods, as keywords in 
understanding epistemological aspects, and; (3) justice, as a keyword in understanding aspects of axiology.

According to Kuntowijoyo the object of science can be in the form of verses of qauliyah, verses of kauniyah and verses of nafsiyah. The verses of qauliyah (divinity / theological sciences) relate to the laws of God, including ways of knowing him and the etiquette of the rites and praying. The verses of kauniyah (natural sciences) relate to natural laws that are real and can be absorbed through human actions in space-time. The verses of nafsiyah (humanities) are related to meaning, value, and consciousness.

In the prophetic paradigm, besides mind, heart, and senses, transcendental revelation is used as a source of knowledge. Revelation acts as a guide in a person's thoughts and actions, and as such he becomes a constitutive element. ${ }^{37}$ It is a priori knowledge as one of the constructors of (as a reference to interpret) reality. ${ }^{38}$

To be able to obtain knowledge from its source, Kuntowijoto epistemologically offers a synthetic and analytic approach. Through a synthetic approach, a revelation in addition to acting as a constituent of values (psychological transformation), also acts as a constituent of theoretical constructs (social transformation). Values (psychological transformation) are formed when appreciation and subjective experience are synthesized with normative teachings, which then form individual ethical and moral perspectives. Whereas theoretical constructs are used to operationalize normative concepts to be objective and empirical

The analytical approach is used to make the main messages that are transcendental in the Qur'an, connected to the context. For this reason, Kuntowijoyo offers a method of transcendental structuralism. Through this method, the text (nash) al-Qur'an will be lifted from its context, namely by transcending the textual meaning of contextual interpretation along with its historical biases.

Through the structuralism approach will be identified and then determined, which part of the results of the synthesis approach to the ideal-type and archetype which plays as the strength forming structure, the structure below, and which is positioned at the empirical level, or surface. It also can be identified and determined which parts of the ideal-type and archetype are immutable, and which can be changed. Therefore it can be seen in which regions the transformation can and will be done.

37 Heddy Shri Ahimsa Putra, 2011, Prophetic Paradigm: Is It Possible - Is It Necessary, ... Loc. Cit. p. 43 (Heddy Shri Ahimsa Putra, 2011, ParadigmaProfetik: Mungkinkah - Perlukah,... Loc. Cit. Hal. 43)

38 Kuntowijoyo, Islam as Science, ... Ibid. p. 18. (Kuntowijoyo,Islam sebagaillmu,... Ibid. Hal. 18) 
Through transcendental, prophetic social science that tries to combine the critical abilities of social science and religious values in a whole and integral frame of the paradigm of science, makes conscious selection of directions. So that social science not only explains and changes social phenomena, but also gives clues to which direction the transformation is carried out, for what, and by whom. Prophetic social science thus not only excites transformation for the sake of change itself but bases its transformation based onparticular ethical and prophetic ideals namely, upholding the good, preventing munkar and believing in Allah SWT (humanization, liberation, and transcendence).

In axiology perspective, prophetic paradigm refers to QS, Ali Imran: 110. According to Kuntowijoyo there are four things implicit in the verse, one of which is about prophetic ethics that can be done by anyone. Prophetic ethics is an integral implementation of (1) ta'murunabilma'ruf = asking/inviting goodness; advocate or uphold virtue; (2) tanhauna 'anilmunkar $=$ preventing from being disbelieved, and (3) tu'minunabillah $=$ believing in Allah. The concepts in QS Ali Imran: 110 namely Amar ma'rufis translated into humanism, na'himunkar is translated into liberation, and tu'minunabillah becomes transcendence. This prophetic ethic is a source of value for the human in determining the benefits of science.

The first element is humanization. Humanization is a creative translation of amarma'ruf whose original meaning is to encourage or uphold virtue. In prophetic, humanization means humanizing humans, eliminating "material things," dependence, violence, and hatred from humans ${ }^{39}$. Humanization is in accordance with the spirit of Western liberalism. It needs to be added soon if Western civilization is born and rests on anthropocentric humanism; the concept of Kuntowijoyo's humanism is rooted in theocentric humanism. Therefore, humanization cannot be understood in its entirety without understanding the background concept of transcendence.

Western humanism was born from a rebellion against the dogmatic Church's authority in the Middle Ages. The anthropocentric view assumes that life is not centered on God but humans. The ethos is the spirit of respecting values built by humans themselves. Anthropocentric civilizations use humans as benchmarks for truth and falsehood, to use humans as beauty criteria and to provide essential values to the parts of life that promise human power and pleasure. Anthropocentrism regards humans as the center of the world, and therefore feels sufficient about themselves. Anthropocentric man feels to be a ruler for

39 Kuntowijoyo, Muslim without Mosque, Op. Cit, pp. 364-365. (Kuntowijoyo, Muslim TanpaMasjid,Op. Cit, Hal. 364-365. 
himself. Not only that, he also went; further, he wanted to be the ruler of others. The universe then becomes the target of its lust, which is increasingly out of control.

With ratios as weapons, anthropocentric humans begin the history of power and exploitation of nature without limits. Modernism, with its banner of rationalism, has proven to cause irreparable damage to nature and humans. Science is a science of war whose methods and tactics of war have been written very intelligently by Descartes through his motto "Cogito Ergo Sum". Through the science of Descartes war, modern civilization creates war machines against nature in the form of advanced technology to conquer and exploit nature without limits, as well as war machines against humans in the form of super modern sophisticated weapons, bombs, and even weapons of mass destruction. So, the ideals of anthropocentric humanism that were originally aimed at realizing humanization actually turned into a process of dehumanization.

Kuntowijoyo then proposed theocentric humanism as a substitute for anthropocentric humanism to elevate human dignity ${ }^{40}$. With this concept, humans must focus on God, but the goal is for the benefit of humanity (humanity) itself. The development of human civilization is no longer measured by rationality but transcendence. Humanization is needed because the community is in three acute states, namely dehumanization (technological, economic, cultural and state objectivity), aggressiveness (collective aggressiveness and crime) and loneliness (privatization, individuation) ${ }^{41}$.

The second element is liberation. Liberation is the creative interpretation of nahi munkar. Liberation in prophetic social science is in accordance with the principles of socialism (Marxism, Communism, dependency theory, liberation theology). ${ }^{42}$ It is prophetic that social science does not want to make its liberation as ideological as communism. Liberation in prophetic social science is in the context of science. Knowledge-based on transcendental noble values. If liberal values in liberation theology are understood in the context of theological teaching, then liberal values in prophetic social science are understood in the context of social science which has a prophetic responsibility to free humans from the cruelty of poverty, extortion of abundance, dominance of oppressive structures and hegemony of consciousness false. On the other hand, if marxism with its

40 About theocentric humanism, read more about Kuntowijoyo, Paradigm. Islam: Interpretation for Action, Bandung: Mizan, 1991, Pp. 228-230 (Tentang humanismeteosentris, bacalebihlanjutKuntowijoyo, Paradigma. Islam: InterpretasiUntukAksi , Bandung : Mizan, 1991, Hal. 228-230)

41 Kuntowijoyo, Muslim without Mosque, Op. Cit, pp. 366-369 (Kuntowijoyo, Muslim TanpaMasjid ,Op. Cit, Hal. 366369.)

42 Kuntowijoyo, New Paradigm of Islamic Sciences: Prophetic Social Sciences as an Intellectual Movement, Mukaddimah Journal, Number 7, Year V / 1999, P. 104. (Kuntowijoyo, ParadigmaBarullmu-ilmu Islam: IlmuSosialProfetikSebagaiGerakanIntelektual, JurnalMukaddimah, Nomor 7, Tahun V/1999, Hal. 104.) 
liberal zeal rejects religion which it considers conservative, prophetic social science instead seeks to rest its liberal zeal on the transcendental prophetic values of religion which have been transformed into objective-factual science.

The aim of liberation is on empirical reality, so liberation is very sensitive to the problem of oppression or structural domination. The phenomenon of poverty born from economic inequality is an essential part of the liberation project. Liberation places itself not on the field of abstract humanity morality, but on the empirical reality of humanity, which is concrete. Kuntowijoyo even considers avoidance from the concrete to the abstract is one of the characteristics of thinking based on myth.

Kuntowijoyo outlines four targets of liberation, namely the knowledge system, the social system, the economic system, and the political system that fetter humans so that they cannot actualize themselves as free and noble beings ${ }^{43}$.

The third element of prophetic social science is transcendence. Transcendence is the basis of two other elements. Transcendence is a concept derived from tu'minuna bi Allah (believing in Allah). Transcendence wants to make transcendental values (faith) an important part of the process of building civilization. Transcendence places religion (Islamic values) at a very central position in prophetic social science.

The negative excesses caused by modernization encourage a passion recapturing the alternatives offered by religion to resolve humanitarian problems. Renaissance products are anthropocentric people who feel that they are the center of the world, enough of themselves. Through the rationalization project, humans proclaim themselves as rulers of the self and the universe. The ratio teaches how to think, not how to live. The ratio creates tools, not consciousness. The ratio teaches humans to master life, not interpret it. Finally, humans live their lives without meaning.

It is where transcendence can play an important role in providing meaning that will direct the purpose of human life. The world is dying, not because of lack of tools or techniques, but because of lack of purpose, the meaning of the people who want to realize God's plan. It is these transcendental God values that will guide humanity to the noble values of humanity.

Transcendence is the basis of humanization and liberation. Transcendence provides direction, and for what purpose humanization and liberation are carried out. Transcendence in prophetic social science aside from functioning as a basis for values for the praxis of

43 Kuntowijoyo, "MenujuIlmuSosialProfetik", Republika (19 Agustus 1997) 
humanization and liberation, it also functions as a critic. With the critique of transcendence, technical progress can be directed to serve human development and humanity, not its destruction. Through criticism of transcendence, society will be freed from materialistic consciousness - where one's economic position determines one's consciousness - towards transcendental awareness. Transcendence will be a measure of human progress and setbacks.

Based on these values, according to the prophetic paradigm, besides aiming at subjectivity, so that humans have the ability and willingness to increase their devotion, they also have objective objectives, namely so that humans can obtain meaning based on correct etiquette and in accordance with objective reality. By obtaining meaning, humans can recognize and recognize the real place of all things in the order of creation, which in the final stages leads to the recognition and recognition of a proper place for Allah in the order of existence and existence. Then, it causes humans to behave and act justly and civilized.

For this reason, humans must struggle wholeheartedly in the history of humanity (having awareness in historical processes), namely humanization (humanizing humans), liberation (freeing people from oppression), and transcendence (bringing people to faith in God).

Surat Ali Imran (3): 110 in addition to being the foundation of Kuntowijoyo in formulating three elements of Prophetic Social Sciences also inspires the importance of awareness in historical processes. Spiritual values (amarma'ruf, nahimunkar) are the foundation of Islamic activism. This role of awareness distinguishes Islamic ethics from materialistic ethics. The Marxist view that superstructure (consciousness) is determined by structure (material base) is contrary to the Islamic view of the independence of consciousness $^{44}$. With this prophetic social science intends to become a new paradigm. Marxism offers a new paradigm with its rules of structure (material base) and superstructure (consciousness) by stating that structure determines super structure. Feminism states that sex (sex) determines consciousness. Prophetic Social Science reverses this formula by placing awareness (superstructure) on a material basis (structure). Kuntowijoyo was convinced that this view would have so much influence on the social sciences and humanities.

HeruNugroho called this view with the term HegellianismRelijius. Kuntowijoyo's view is not much different from understanding the ideas of the followers of Hegel.

44 Kuntowijoyo, Muslim Tanpa Masjid, Op.Cit, hlm. 358. 
However, there is a fundamental difference that is that in Hegelian idealism, rational awareness (absolute spirit) is the driving force of human history, while in the paradigm of Prophetic Social Sciences, the consciousness that drives history is an awareness based on divine values ${ }^{45}$.

Social science has been oscillating between the two extremes of determinism. Marxism embraces material determinism with the concept that structure determines superstructure, while Weberian sociology embraces determinism of consciousness. Weber believes that consciousness is independent of the material base; hence ideas can drive change.

Prophetic Social Sciences, at first glance, looks close to this concept of Weber. However, this impression does not seem too right because Kuntowijoyo actually also recognizes material awareness. Material awareness is consciousness determined by its material base ${ }^{46}$.

The deterministic view, both material determinism, and determinism of consciousness are both a-historical and a priori towards reality. In Marxist logic, the structure is objective, in the sense of being independent of human will (subjectivity, consciousness). Therefore, human consciousness, will, and subjectivity (superstructure) becomes meaningless because structure determines superstructure. Human subjectivity is subordinated under material objectivity. In reality, there has never been a total submission. Material objectivity is often very hegemonic, but subjectivity is never truly able to be subdued. There are always emancipatory spaces for the subjectivity of human consciousness to get out of material hegemony.

On the contrary, the logic of determinism of consciousness will state that subjectivity, ideas, and consciousness will determine the structure (material base) because superstructure determines structure. This view denies the reality that there are people whose consciousness is very materialistic. Material awareness is consciousness, which is strongly influenced by its material conditions. Therefore, both forms of determinism are equally problematic, because reality is actually dialectical, not deterministic. Social reality runs on dialectical tension between structure and superstructure, between the material base and consciousness, between material objectivity and human subjectivity.

45 HeruNugroho, "Looking for Academic Legitimacy of Prophetic Social Sciences", People's Sovereignty, (13 December 1997). (HeruNugroho, "MencariLegitimasiAkademikIlmuSosialProfetik", KedaulatanRakyat , (13 Desember 1997).)

46 Kuntowijoyo, Political Identity of the People, Op.Cit, p. 224. (Kuntowijoyo, IdentitasPolitikUmat, Op.Cit, Hal. 224.) 
In such contexts, prophetic social science is not trapped in deterministic logic, which is a priori towards reality. It means to determine whether the material dimension or awareness at that time is more influential, Prophetic Social Science bases itself on empirical observations of reality. Because reality is too complex to be explained through deterministic concepts. The deterministic view will actually force reality to follow the theory, whereas the theory should be based on reality, not vice versa.

Nevertheless, it is important for Prophetic Social Sciences to continue to have ethical alignments so that they can continue to play their critical functions in dealing with reality. In this context, we can agree with Kuntowijoyo's statement that consciousness is placed on a material basis because Islam idealizes the critical function of consciousness in the process of social transformation.

\section{CONCLUSION}

Prophetic can be used as one model to integrate science and religion, which is done by connecting the text with the context. Keywords that can be used as a guide to understanding the prophetic paradigm of Kuntowijoyo, are: (1) verses of qauliyah, verses of kauniyah and verses of nafsiyah; revelation, reason, heart, and sensesas a keyword in understanding aspects of ontology; (2) synthetic and analytic approaches with transcendental structural methods, as keywords in understanding epistemological aspects, and; (3) justice which is based on prophetic ethical values: humanization, liberation, and transcendence, as keywords in understanding the axiological aspects.

\section{REFERENCE}

Al-Attas, Syed Muhammad Naquib. (2010). Islam and secularism. Translated by Khalif Muammar (et al). Islam and secularism. Bandung: Institute for Islamic Thought and Human Development (LEAD) in collaboration with the Nature and Tamadun Malay Institute (ATMA), Kebangsaan University, Malaysia. (Al-Attas, Syed Muhammad Naquib. (2010). Islam and Secularism. diterjemahkan oleh Khalif Muammar (dkk). Islam dan Sekularisme. Bandung : Institut Pemikiran Islam dan Pembangunan Insan (PIMPIN) bekerjasama dengan Institut Alam dan Tamadun Melayu (ATMA) Universitas Kebangsaan Malaysia.)

Armas, Adnin. (2007). Dewesternisasi and Islamization of Science. the paper was presented at a discussion on INSISTS on May 19, 2007. (Armas, Adnin. (2007).Dewesternisasi dan Islamisasi Ilmu Pengetahuan. .makalah disampaikan dalam diskusi sabtuan INSISTS pada tanggal 19 Mei 2007.) 
Armas, Adnin. (2007). The Crisis of Epistemology and the Islamization of Science. Ponorogo: ISID Gontor: Center for Islamic and Occidental Studis. 2007. (Armas, Adnin. (2007). Krisis Epistemologi dan Islamisasi Ilmu. Ponorogo: ISID Gontor: Center for Islamic and Occidental Studis. 2007.)

Bagir, Zainal Abidin. (2005). Islamic Science and Integration of Science with Ethics: Kuntowijoyo's Idea. delivered at the Kuntowijoyo Life and Thought Appreciation seminar. at the UGM University Center. May 26, 2005. (Bagir, Zainal Abidin. (2005). Pengilmuan Islam dan Integrasi Ilmu dengan Etika: Gagasan Kuntowijoyo. dalam seminar Apresiasi Hidup dan Pemikiran Kuntowijoyo. di University Center UGM. 26 Mei 2005.)

Bosetti, Giancarlo. (2009). Thought to Find a Point of Contact. in Giancarlo Bosetti (ed.). Faith Against Reason: Joseph Ratzinger's Debate Against Jürgen Habermas. Yogyakarta: Canisius Publishers. (Bosetti, Giancarlo. (2009). Pemikiran untuk Mencari Titik Temu . dalam Giancarlo Bosetti (ed.). Iman Melawan Nalar: Perdebatan Joseph Ratzinger Melawan Jürgen Habermas. Yogyakarta : Penerbit Kanisius.)

Capra, Fritjof. (2009). The Tao of Physic: An Exploration of The Parallels bertween Modern Physics and Easter Mysticism. Translated by Aufiyah Ilhamal Hafidz. The Tao of Physic: Menyingkap Kesejajaran Fisika Modern dan Mistisme Timur. 4th Edition. Yogyakarta : Jalasutra Publisher.

Casanova, José. (2006). Secularization Revisited: A Reply to Talal Asad. dalam David Scott dan Charles Hirschkind (eds.). Powers of the Secular Modern: Talal Asad and His Interlocutors. Stanford. California: Stanford University Press

Dhakidae, Daniel. (2003). Scholars and power in the New Order State. Jakarta: PT. Gramedia Main Library. (Dhakidae, Daniel. (2003). Cendikiawan dan kekuasan Dalam Negara Orde Baru. Jakarta: PT. Gramedia Pustaka Utama.)

Fahmi, M ... (2005). Transcendental Islam (Tracing traces of Kuntowijoyo's Islamic Thought). Yogyakarta: Media Pillar. (Fahmi, M.. (2005). Islam Transendental (Menelusuri jejak-jejak Pemikiran Islam Kuntowijoyo). Yogyakarta: Pilar Media.)

Golshani, Mehdi. (2003). Science and the Sacred: Sacred Science vs. Secular Science. Paper of International Conference on Religion and Science in the Post-Colonial World. Yogyakarta: Universitas Gajah Mada. 2-5 Januari

Habermas, Jürgen. (2009). Matters Recognized by Non-Religious Philosophers About God (again from Rawls). in Giancarlo Bosetti (ed.). Faith Against Reason: Joseph Ratzinger's Debate Against Jürgen Habermas. Yogyakarta: Canisius Publishers. (Habermas, Jürgen. (2009). Hal-hal yang Diakui oleh Filsuf Non-Religius Tentang Tuhan (lagi dari Rawls). dalam Giancarlo Bosetti (ed.). Iman Melawan Nalar: Perdebatan Joseph Ratzinger Melawan Jürgen Habermas. Yogyakarta : Penerbit Kanisius.)

Hardiman, F. Budiman. (2003). Beyond Positivism and Modernity: Philosophical Discourse on the Scientific Method and the Problem of Modernity. Yogyarakta: Canisius Publishers. (Hardiman, F. Budiman. (a 2003). Melampaui Positivisme dan 
Modernitas: Diskursus Filosois tentang Metode Ilmiah dan Problem Modernitas. Yogyarakta :PenerbitKanisius.)

Kartanegara, Mulyadhi. (2007). Islamizing Reason: A Response to Modernity. Jakarta: Erlangga Publisher. (Kartanegara, Mulyadhi. (2007). Mengislamkan Nalar: Sebuah Respon terhadap Modernitas. Jakarta : Penerbit Erlangga.)

Kleden, Ignas. (2010). Post-Secular Society: Relationship of Intellect and Faith and New Adjustments Demands. speech text of the Studium Generale Faculty of Theology at Sanata Dharma University. Yogyakarta August 16, 2010. (Kleden, Ignas.(2010).Masyarakat Post-Sekular:Relasi Akal Dan Iman SertaTuntutan Penyesuaian Baru. teks pidato Studium Generale Fakultas Teologi Universitas Sanata Dharma. Yogyakarta 16 Agustus 2010.)

Kuntowijoyo (1991). Paradigm. Islam: Interpretation for Action. Bandung: Mizan. (Kuntowijoyo. (1991). Paradigma. Islam: InterpretasiUntukAksi .Bandung :Mizan.)

Kuntowijoyo (1997). "Towards Prophetic Social Sciences". Republika (August 19, 1997) (Kuntowijoyo. (1997) . "MenujuIlmuSosialProfetik". Republika (19 Agustus 1997))

Kuntowijoyo (1997). Political Identity of Muslims. Bandung: Mizan. 1997. (Kuntowijoyo. (1997). Identitas Politik Umat Islam. Bandung: Mizan. 1997.)

Kuntowijoyo (1999). The New Paradigm of Islamic Sciences: Prophetic Social Sciences as an Intellectual Movement. Mukaddimah Journal. Number 7. Year V / 1999. (Kuntowijoyo. (1999). ParadigmaBarullmu-ilmu Islam: IlmuSosialProfetikSebagaiGerakanIntelektual. JurnalMukaddimah. Nomor 7. Tahun V/1999.)

Kuntowijoyo (2001). Muslim without mosque. Bandung: Mizan. (Kuntowijoyo. (2001). Muslim Tanpa Masjid. Bandung: Mizan.)

Kuntowijoyo (2004). Islam as a Science. Bandung: Teraju. (Kuntowijoyo. (2004). Islam Sebagai Ilmu. Bandung: Teraju.)

Naisbitt, John. (1997). The Eight Megatrends that are Changing the World. Translated by Danan Priyatmoko dan Wandi S. Brata. Megatrends Asia: Delapan megatrend Asia yang Mengubah Dunia. Jakarta: Periplus Editions dan PT. Gramedia Pustaka Utama.

Nugroho, Heru. (1997). "Looking for Academic Legitimacy of Prophetic Social Sciences". People's Sovereignty. (December 13, 1997). (Nugroho, Heru. (1997). "MencariLegitimasiAkademikIlmuSosialProfetik". KedaulatanRakyat . (13 Desember 1997).)

Putra, Heddy Shri Ahimsa. (2011). Paradigma Profetik: Mungkinkah? Perlukah?. Paper presented in the "Sarasehan Profetik 2011" (2011 Prophetic Workshop). Organized by UGM Postgraduate School. di Yogyakarta. 10 Februari 2011.

Rachman, Budhy Munawar. (2001). Pluralist Islam: Discourse on Equality of the Faith. Jakarta: Paramadina. (Rachman, Budhy Munawar. (2001). Islam Pluralis: Wacana Kesetaraan Kaum Beriman. Jakarta: Paramadina.) 
Ratzinger, Joseph. (2009). Reason and Faith: Reciprocity Exchange to Build a General Ethic. in Giancarlo Bosetti (ed.). Faith Against Reason: Joseph Ratzinger's Debate Against Jürgen Habermas. Yogyakarta: Canisius Publishers. (Ratzinger, Joseph. (2009). Nalar dan Iman: Pertukaran Timbal Balik untuk Mambangun Suatu Etika Umum. dalam Giancarlo Bosetti (ed.). Iman Melawan Nalar: Perdebatan Joseph Ratzinger Melawan Jürgen Habermas. Yogyakarta : Penerbit Kanisius.)

Sardar, Ziauddin. (1987). The future of Islam. Bandung: Salman Library (Sardar, Ziauddin. (1987). Masa Depan Islam. Bandung: Pustaka Salman.)

Faithful, Adi. (2007). Three Meanings of Islamic Science: Towards Operationalization of the Islamization of Science. Journal of Islamic thought and civilization. Vol. III. No. 4. 2007. Jakarta: INSISTS and Khairul Bayan Publishers. (Setia, Adi. (2007).Tiga Makna Sains Islam : Menuju Pengoperasionalan Islamisasi Sains. Jurnal Pemikiran dan peradaban Islam. Vol. III. No. 4. 2007. Jakarta: INSISTS dan Penerbit Khairul Bayan.)

Subeno, Sutjipto. (2011). Fritjof Capra's Science-Mystical Paradigm: A Critical Review From a Christian Perspective. http://www.grii-andhika.org/makalah penting.htm. (Subeno, Sutjipto. (2011). Paradigma Sains-Mistis Fritjof Capra: Suatu Tinjauan Kritis Dari Sudut Pandang Iman Kristen. http://www.griiandhika.org/makalah_penting.htm.)

Suseno, Franz Magnis. (2005). Incandescent Philosophy: From Gotholoco to Women's Philosophy. from Adam Müller to Postmodernism. Yogyakarta: Canisius Publishers (Suseno, Franz Magnis. (2005). Pijar-Pijar Filsafat : Dari Gotholoco ke Filsafat Perempuan . dari Adam Müller ke Postmodernisme. Yogyakarta : Penerbit Kanisius)

Sutanto, Trisno S. (2010). Saving Secularization. Saving Religion: Notes on Post-Secular Societies. paper presented at the monthly discussion of the Jakarta Salihara Community. December 2010. (Sutanto, Trisno S. (2010). Menyelamatkan Sekularisasi. Menyelamatkan Agama: Catatan tentang Masyarakat Post-Secular. makalah yang disampaikan dalam diskusi bulanan Komunitas Salihara Jakarta. Desember 2010.)

Wan Daud, Wan Mohd Nor. (2008). "Dewesternization and Islamization: Their Epistemic Framework and Final Purpose". Paper presented at a seminar on the theme of Islamization of Contemporary Sciences "organized by the Institute for Islamic Studies and Practices (LPPI) Yogyakarta Muhammadiyah University in collaboration with the Yogyakarta Institute of Thought (IPI Jogja) on December 13, 2008. (Wan Daud, Wan Mohd Nor. (2008). "Dewesternization and Islamization : Their Epistemic Framework and Final Purpose”. Makalah yang dipresentasikan dalam seminar dengan tema Islamisasi Ilmu-ilmu Kontemporer" yang diselenggarakan oleh Lembaga Pengkajian dan Pengamalan Islam (LPPI) Universitas Muhammadiyah Yogyakarta bekerjasama dengan Institut Pemikiran Yogyakarta (IPI Jogja) pada tanggal 13 Desember 2008.)

Zarkasyi, Hamid Fahmy. (2010). Efforts to rebuild a dignified Islamic civilization. in Laode M. Kamaluddin (Ed.). On Civilization: Reigniting the Lanterns of Islamic Civilization that Had Extinguished. Semarang: Unissula-Press in collaboration with Publisher Republikata. (Zarkasyi, Hamid Fahmy. (2010). Ikhtiar Membangun kembali 
Peradaban Islam yang bermartabat. dalam Laode M. Kamaluddin (Ed.). On Civilization : Menyalakan Kembali Lentera Peradaban Islam yang Sempat Padam. Semarang : Unissula-Press bekerjasama dengan Penerbit Republikata.) 